\title{
Youthizen, Political Literacy, and Social Media
}

\author{
Nuriyatul Lailiyah ${ }^{1}$, Much. Yuliyanto ${ }^{2}$, Ghozian Aulia Pradhana ${ }^{3}$ \\ ${ }^{1,2}$ Department of Communication, University of Diponegoro, Semarang, \\ ${ }^{3}$ Department of Public Relations, University of Diponegoro, Semarang,
}

\begin{abstract}
The engagement between young generation and social media in Indonesia is crystal clear. On the one hand, politicians are aware that social media is an efficient and effective medium for interacting with society. It can be seen that, there's open chance for politician to embrace social media as their medium to interact with "youthizen" (youth netizen). This research aimed to describe the role of social media in building the political consciousness of the young generation. By using mixed methods (survey for quantitave method and depth interview for qualitative method) to high school students and those who influence their social media habit. The result showed that youthizen have strong engagement with social media but low political awareness. They're even disaggree to the usage of social media for their own political personal opinion. It also showed that they're vulnerable in facing social media hoax. Those situations might put them as targets by dirty political intension.
\end{abstract}

Keywords: Youthizen; Political Literacy; Social Media; Hoax; Political Talks

\section{Introduction}

There are many definitions of political literacy. Political literacy means the state of having political information [1]. Based on it, we can assume that if a person know names of presidential candidate that run in an election then he/she is politically literate. this definition emphazise political literacy in cognitive aspect. Another definition of political literacy could also be defined as the state of individuals to be acquainted with the political process and political affairs as effective citizens in order to fulfill their roles and comprehension of these issues by individuals [2]. The substance is quite similar to previous definition of political literacy which was focused on cognitive aspect.

Another definitions showed that political literacy is more than just knowledge. It required attitude and behaviour aspect to fulfill the term. Skills require an affective participation in the social life; however, unless the individual is enabled to participate, these skills can not be expected to develop. A politically literate citizen is not only an informed beholder. Being a politically literate citizen, the individual is an active participant in social events, regarding her/his own issues [3]. A politically literate citizen not only comprehends her/his current state, but also gets involved in the state in an active and effective way and directs it. An individual with the skill of political literacy has the skills of understanding other people's viewpoints, realizing their effect upon her/him and responding to them in an ethical way [3]. Additionally, a politically literate person has the basic knowledge, skills and values regarding how to express her/himself in everyday life [4].

Combining all those definitions of political literacy, the writers agreed that it consist of three aspect: cognitive, attitude/affective, and behaviour aspect. Cognitive means people need to have sufficient information about political situations surround them. In order to be able to form a particular attitude of opinion about certain political issues or situations. Expressing political thought and opinion and participating in a spesific political action such as election, supporting or criticizing the ruling government, surveiling public services in order to keep them in right direction, and etc.

Political literacy is urgently required in facing nowadays phenomenon. Spesifically in social media, we are overwhelmed by the flood of political information and news that that need to be clarified and cross checked. Meanwhile, the ability in selecting and filtering information on our society is recently on test. The death of TV technician that was yelled thief by angry mob [5], the chaos in YLBHI office in Jakarta that was caused by hoax [6], and last but not least, Jakarta recent governor election. We could easily find hoaxes in social media, even terrors and fear might came out due to political preferences.

The fact that numbers of netizen in Indonesia are mostly young generation aged 20-29 years old (80\%) [7]. The domination of youthizen (young netizen) in Indonesia showed that they are the one 
who could easily become targets of political hoaxes and political provocative information that could harm unity in Indonesia. Social media is the most consumed content by youthizen in internet. It could put youthizen as vulnerable target for political hoaxes and political provocative information. The youthizen need to be politically literate in order not to be mobilizied in opinion and attitude.

\section{Methodology}

The method of this research is mixed method. The research data was gathered through survey to 100 senior high school students in Semarang that have social media accounts. Indepth interview was done by interviewing people that were mentioned by students as their political response influencer. Family and peers were interviewed to collect qualitative data.

\section{Discussion}

Research showed that family (59\%) and peers (37\%) are those who influenced respondents most in responding political message in social media. Based on the interviews to respondents's family, political discussion is part of daily family life. Besides its function as medium for self expression, social media is also youthizen's tool to search information. Entertaintment is the most searched information (69\%) along with social politics (14\%), economy $(9 \%)$, and religion $(8 \%)$. Those results indicated that it is very important for youthizen to be politically literate considering political information also what they are looking for in social media. while information that is scattered in social media especially related to politics is usually a subjective view of a person and sometimes even fake or hoaxes. In addition to seek information, social media is also used by respondents to share entertainment information (66\%), economy (18\%), religion (12\%), and social politics (4\%). Entertainment is once again a favorite among youthizens.

If we look at the views of respondents about political literacy, the majority of respondents interpret political literacy as an effort to awaken people to be aware and participate in politics (40\%), politics related activities (28\%), education to know and care politics (20\%), and activities that educate and make people literate about politics (12\%). The answer above shows in general that youthizen has knowledge related to political literacy. It also showed that making them aware and critical of political information and situation is not a very difficult thing. Since their cognitions were exposed to the concept of political literacy.

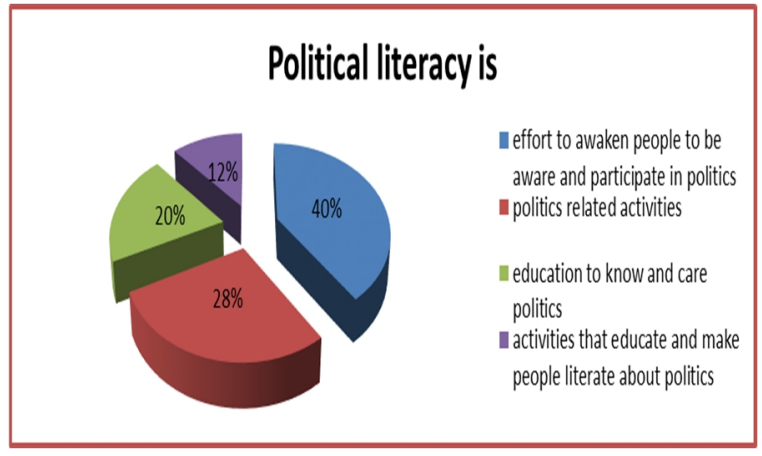

On the other hand, the majority of respondents interpreted politics solely to the government and power (49\%), political parties and elections (10\%), as well as office and position (6\%). Those meanings is associated with politics as something related to ambition, hustle and bustle, dominance, and things that tend to be negative. Only $35 \%$ of respondents considered politics as a strategy and a means of realizing the public interest. Researchers see that youthizen's definitions to politics are what made youthizen tended to use their social media as a means of entertainment amidst the hectic political conversations in social media in Indonesia lately.

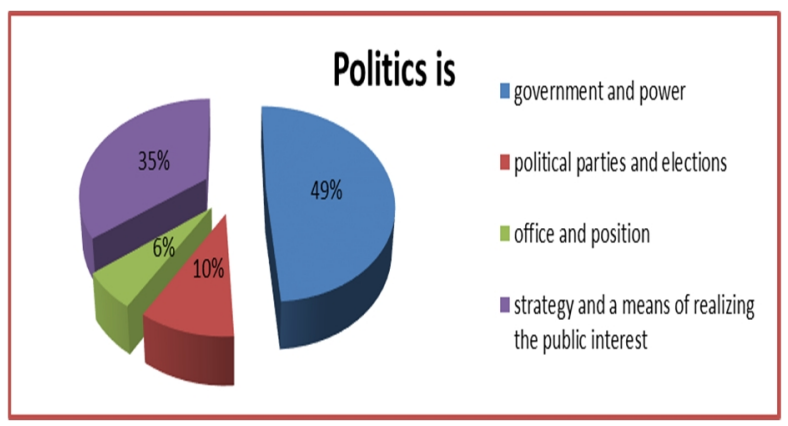

Negative views about politics are then consistent with respondents' attitude which most of them disagreed to express their political opinion and thoughts via use social media (69\%). Only $18 \%$ of respondents agreed and $1 \%$ strongly agreed. $12 \%$ of other respondents even strongly disagree with the activity. We can also see that political issues rarely appear in their social media timeline. As many as $57 \%$ of respondents disagreed and $25 \%$ strongly disagreed that $>30 \%$ of the content on their timeline is related to politics. Only $18 \%$ of respondents agreed. This means that their networks in social media are not among those who interested in political issues. Social media networks usually consist of friends, family, social media selebrities, and institutions account. And social media users have big authority to manage what issues may arise and not on their timeline. We could easily cancel friendships or unfollow someone in social media when we disliked or disturbed by certain issues conveyed by an account. This at once showed that basically the interest of the respondents on political 
issues is low. So they prefer their social media content more entertainment than politics.

Early teenager voters would tend to access online to find information, address questions and, most important to form opinions. Those situations are is widely influenced by other social media users, as well as information provided by political parties, the ability to participate in dialogue with voters, and the overall sentiment prevalent around leaders to vote. Conversations are also possible and available to undecided voters. Adolescents tend to pay attention to how communication patterns are built through their social media. In these cases students typically use some social media accounts specifically among their peers [8].

The condition is also reflected in the partners of political-themed talks. Respondents mostly discussed political themes with their families (63\%) compared with friends (44\%). The answer is also an indication that social media chats are keeped to be less political by youthizens. However it showed consistency between friendship relationships in social media compared to real life friendship relationship, that political-themed talks gets a small portion. Respondents themselves avoided the role of political message-themed producers in social media. The majority of them refused to share political information in social media $(80 \%)$. This is in order to keep social media remains entertained. This also can be interpreted that politics is not interesting enough to be discussed among friends. It is supported by the finding that $83 \%$ of respondents are not used to discuss politics in social media. but in the real world more respondents are accustomed to political discussion although the numbers are also small. as many as $32 \%$ of respondents confirmed that they are accustomed to discussing politics in the real world.

The offline activity of passing word-of-mouth information is carried out, whereby those who passively consume or engage with chats carry offline opinion to friends, family and colleagues, thus making it a source of great influence even in the physical world. From the Durkheimian point of view, all individuals must be socially integrated in some way [9]. How it is formed between individuals and according to the place where they live, including the physical world. They show the intensity of interaction intimacy, volume, number of people covered by interaction and the regularity and adherence to such interactions. So the offline community among teens optimized messages for the use of their opinions. The process of understanding messages through word of mouth activity ultimately determines decisions and dominance in their minds about the world of politics.

Based on the previous definitions of political literacy, research showed that youthizen as respondents in this research were not having the capacity in political literacy. Most of respondents had sufficient knowledge in knowing the basic definiton of political literacy, but not enough participation and possitive attitude related to political literacy. Becoming concerned about politics in daily life and showing some political expression in daily and social media life are manifestation of politically literate attitude. However neglecting and avoiding political issues in social media is a sort of indication of political ignorance. Political ignorance can lead to low level of political literacy.

\section{Conclusion}

Youthizen prefer use their social media as an entertainment tool. They dont feel comfortable showing their political expression and connected to political issues through their social media. Family are better partner for youthizen in talking about politics than their friends or peers. Real life is a better world to talk about politics than social media. Those situations might lead to low capacity in political literacy for youthizens. And it shows that media social did not rule political awareness and attitude of youthizen since they wanted to keep their media social clean from political issues.

Thus political influence can also have an impact on the environment. politicians can also influence the media to expose environments that need attention.

\section{References and Notes}

1. J. A. Krosnick, "Expertise and Political Psychology", Social Cognition Chapter 8 pp 1-8 (1990).

2. D. Denver and G. Hands, "Does Studying Politics Make a Difference? The Political Knowledge, Attitudes, and Perceptions of School Students", British Journal of Political Science 20 pp 263-288 (1990).

3. L. Fyfe, "Hidden in the Curriculum: Political Literacy and Education for Citizenship in Australia", Melbourne Journal of Politics, Vol. 32, pp. 110-134 (2007).

4. Z. Kus, "Political Literacy Status of Pre-Service Social Studies Teacher", Procedia - Social and Behavioral Sciences vol. 177 pp 197-202, retrieved from http://doi.org July 2014 (2015).

5. New York Times, "Indonesia Vigilante Lynching", https://www.nytimes.com retrieved 11.09.17 (2017).

6. The Jakarta Post, "Fake PKI News Behind Anti Communist Chaos LBH YLBHI", http://www.thejakartapost.com/ retrieved 11.09.17 (2017).

7. Washington Post, "Anti Communist Mob Attacks Indonesia Meeting, 22 Arrested", https://www.washingtonpost.com.html retrieved 11.09.17 (2017). 
8. A. Biswas, N. Ingle, and M. Roy, "Influence of Social Media on Voting Behavior", volume 2(2) pp 127-155 (2014).
9. D. Holmes, "Teori Komunikasi Media, Teknologi, dan Masyarakat", Pustaka Pelajar, Yogyakarta (2012) 